\title{
The Influence of System User Ethics in Increasing the Effectiveness of Accounting Information Systems
}

\author{
Elly Halimatusadiah \\ Faculty Economic and Business Department Accounting, Universitas Islam Bandung \\ Affandi Iss \\ Faculty Economic and Business Department Management, Universitas Islam Bandung \\ Hariani \\ Faculty Economic and Business Department Accounting, Universitas Islam Bandung \\ Azkia Ibadina S \\ Faculty Communication, Universitas Islam Bandung \\ Nunung Nurhayati* \\ Faculty Economic and Business Department Accounting, Universitas Islam Bandung
}

\begin{abstract}
System User Ethics is the most important part in increasing the effectiveness of accounting information systems. Where ethics as a moral agent in making choices to guide his behavior, and when the system is applied ethics is an important part in increasing the effectiveness of accounting information systems. The purpose of this study was to determine how much influence the ethics of system users have on the effectiveness of accounting information systems. The research method uses descriptive verification, data collection techniques use questionnaires, and the data is tested for validity and reliability. The population is Islamic banking employees, with a sample of 59 Islamic Commercial Bank employees who are directly related to the research. The test tool used is simple linear regression. The results showed that the ethics of system users had a significant effect on the effectiveness of the Islamic banking accounting information system.
\end{abstract}

Keywords: Ethics user system, the effectiveness of the accounting information system, Islamic banking

DOI: $10.7176 /$ RJFA/12-20-03

Publication date:October $31^{\text {st }} 2021$

\section{INTRODUCTION}

The information system is a set of interrelated components that starting from the collection, processing, storing and distributing information to support decision making and control of an organization (Laudon \& Laudon, 2012). Information systems have a very important role in a business entity (Nukabadi \& Middle, 2006), because information systems facilitate the strategy formulation process and improve complementary relationships within the organization and supervisory activities (Nicolaou, 2011). Information systems are built from various components, including: purchased or custom-built software, hardware, and networks (Bentley \& Whitten, 2007). Many factors affect the effectiveness of information systems including the ethics of system users.

According to Laudon \& Laudon (2014), ethics are principles of right and wrong that can be used by individuals, acting as free moral agents, in making choices to guide their behavior. When the information system is implemented, ethics becomes very important as a guide for management in the context of developing the technology that is being applied (Piccoli, 2008), as well as according to Rogerson et al (2000) ${ }^{11}$ that ethics is related to the development of information systems. Likewise, according to Sri Dewi (2019) ${ }^{12}$ that user ethics is a moral principle for someone related to good and bad behavior in carrying out Accounting Information System activities, but the results of his research prove that BUMN employees have not fully adopted the ethics of users in using accounting information systems. , while the results Nila Hidayah $(2018)^{13}$ proves that the ethics of the effect on the use of information systems

Based on the above background, the identification of the problem is how ethical users of the system can improve the effectiveness of accounting information systems in islamic banking in order to improve the quality of accounting information is accurate and relevant as a management decision-making tool so that the performance of Islamic banking is increasi

\section{THEORETICAL FRAMEWORK}

User

Ethics Ethics development in the development of information technology at this time is very important, especially in the information age as it is today. Where IT players must know ethics in the use of Information 
System Technology. The word Ethics comes from the Ancient Greek: "ethikos", which means "arising from habit". Ethics is something where and how the main branch of philosophy that studies values or qualities is the study of moral standards and judgments. Ethics includes the analysis and application of concepts such as right, wrong, good, bad, and responsibility. According to Laudon \& Laudon (2014) human behavior that has the freedom to choose individually is called ethics. Similarly, according to Dessler (2013) who says that ethics refers to the principles of behavior that govern individuals or groups that use standards of behavior that must be carried out. Likewise according to (Schwalbe, 2006) that ethics is very important in the implementation of all professions.

Users are people who use information technology to help solve problems and make their work easier, ethics for users is not to do or use applications piratedthat can harm creators, respect other people's copyrights, do not damage information technology.

\section{User Ethics Indicators}

When an individual or a person is faced with various alternative actions, he will use ethics as a basis for determining the best choice. So ethics here will be related to one's choice. Ethical choices are decisions made by individuals who are responsible for the consequences of their actions. Laudon \& Laudon (2014:159) ${ }^{30}$ argues that there are three elements that become the basic concept in carrying out ethical actions, namely: "Responsibility, Accountability and Liability".

1) Responsibility (accountability) is the primary key of ethical action which means accepting of all forms of fees, duties and the necessity of a decision made

2) Accountability is a feature of the system and social institutions. This means demonstrating appropriate mechanisms for determining who is responsible for taking action and who is responsible for those decisions. Systems and institutions that are not able to find people who deserve certain actions are basically unable to provide ethical analysis or ethical actions.

3) Liability is an extension of the concept of responsibility that leads further into the legal field. Liability is a feature of the political system in which a legal entity in one place allows a person to receive reparation for the damage caused to him or her caused by another person, system or organization.

\section{Quality of Accounting Information Systems}

According to Hall (2011) said that "Accounting information system is a subsystems process of financial transactions and non-financial transactions that directly affect the processing of financial transactions". This means that the accounting information system is a subsystem of the process of financial transactions and nonfinancial transactions that directly affect the processing of financial transactions. Likewise, the opinion of Azhar Susanto (2013) that: The Accounting Information System is a collection of subsystems that are interconnected with each other and work together in harmony to process financial data into financial information needed by decision makers in the decision-making process. Meanwhile, according to Goetsch \& Davis (in Hessel Nogi S. Tangkilisan, 2007) "Quality is a dynamic condition associated with products, services, people, processes, and the environment that meet or exceed expectations."

While the understanding of the Quality of Accounting Information Systems according to Azhar Susanto (2013:16) is as follows: The quality of accounting information systems is a data processing system that is integrated and harmonized between the components of the accounting information system to produce financial information and other information to those in need.

\section{Indicators of the Quality of Accounting Information Systems}

There are five dimensions ofquality system according to Heidman (2008) including integration, accessibility, flexibility, formalization and media enrichment, while DeLone and McLean (2003) show that the dimensions of system quality are ease of use, system flexibility, system reliability and ease. of learning. Based on some of the definitions above, in this study the dimensions that will be used are integration, accessibility and flexibility, where the integration to be measured is the integration between components and integration between subsystems (Azhar 2013). While the accessibility to be measured is being able to be accessed easily and able to be accessed in various locations and Flexibility can be measured by being able to adapt to user needs and being able to adapt to changing conditions.

\section{System User Ethics on the Quality of Accounting Information Systems}

Laudon \& Laudon (2014: 152) states that one must understand how the correct ethics are needed in the use of information systems. This is in line with Rocheleau (2006:264), that ethics is related to information systems. Furthermore, O'Brien \& Marakas (2011:20) emphasized that as managers, professional entrepreneurs and employees must have ethical responsibilities in the use of information systems. The results of a study conducted by Myers \& Venable (2014) concluded that there are 6 ethical principles that must be applied in the use of 
information systems, including the public interest, informed consent, privacy, honesty and accuracy, property and quality of the artifact. Similarly, the results of research by Rogerson et al (2000) that ethical problems are related to the implementation of information systems, if ethical behavior is applied carefully and validated with work results, it is necessary to have good ethics in the use of information systems.

Based on the description above, the implementation of information systems in an organization pays attention to the ethics of system users, so it can be said that ethics affects the quality of accounting information systems.

\section{RESEARCH METHOD}

Methods used in this study is explanatory research. This study is designed to understand or analyze the relationship and influence between exogenous variables on endogenous variables. While the types of data used are primary data and secondary data. Data was collected by giving questionnaires and interviews to system users at Islamic banks (BUS) in Indonesia. The population in this study is Islamic commercial banks in Indonesia as many as 13 BUS, with a slovin sample obtained as many as 10 BUS, each BUS was given 6 questionnaires for system users. accounting information in Islamic Commercial Banks. The data is tested first with validity and reliability tests, and statistical test tools for hypothesis testing using simple linear regression

\section{RESULTS AND DISCUSSION}

\section{Overview of System User Ethics Variables System User Ethics}

Variables have 12 statement items consisting of 3 dimensions, namely the responsibility, accountability and liability dimensions, where responsibility consists of 4 statements, accountability consists of 4 statements, and the liability dimension consists of 4 statement items.

will be presented and explained the tendency of respondents' answers to the system user Ethics variable consisting of the dimensions of responsibility, accountability and liability with a frequency and percentage distribution approach.

1. Responsibility

following is presented in the table recapitulation of respondents' responses that have been proposed to measure the information user ethics variable through the responsibility dimension which consists of 4 statement items.

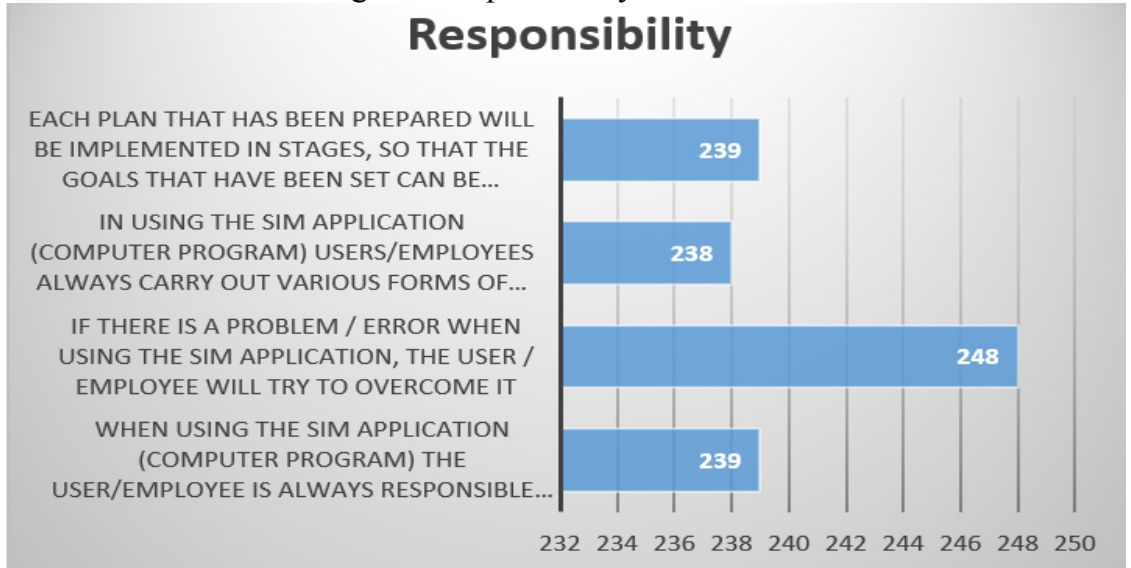

Figure 1: respondents' answers about responsibility

Based on the picture above, in statement (P1) the majority of respondents answered agree, which means that whenusing the SIM application (computer program) the user/employee is always responsible for the work done is good with a score of 239 . Meanwhile, in a statement (P2) the majority of respondents agree that means if there are problems / errors when using the SIM application, then the user / employee will attempt to overcome her well witha score of 238. While the statement (P3) the majority of respondents agree that means that in the use of SIM applications (computer programs) users/employees always carry out various forms of work that have been well planned in advance with a score of 248 , as well as question (P4) the majority of respondents answered agree, which means that every plan that has been prepared will be implemented gradually, so that the goals that have been set $\mathrm{n}$ can be achieved optimally and well with a score of 239 .

2. Accountability

following is presented in the table of respondents' responses that have been proposed to measure the accountability dimension, consisting of 4 statement items. 


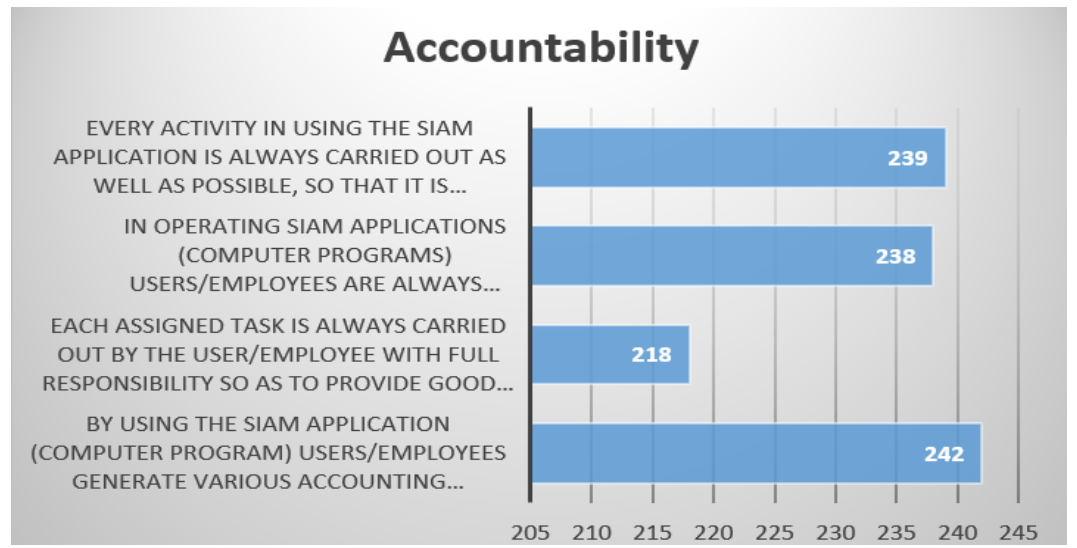

Figure 2: respondents' answers about Accountability

Based on the picture above, in statement (P1) the majority of respondents answered agree, which means that when using the SIM application (computer program) the user/employee is always responsible for the work that is done well with a score of 239. Meanwhile in statement (P2) the majority of respondents answered agree which means If there are obstacles / errors when using the SIM application, then users / employees will try to handle it well with a score of 238. While in statement (P3) the majority of respondents answered agree which means in using SIM applications (computer programs) users/employees always carry out various forms of work that have been well planned in advance with a score of 218, as well as question (P4) the majority of respondents answered agree, which means that every plan that has been prepared will be implemented in stages, so that the objectives that has been set can achieved optimally and well with a score of 242 , which means that the ethics of users in Islamic banking in terms of accountability is good.

3. Liability

following is presented in the table of respondents' responses that have been proposed to measure the accountability dimension, consisting of 4 statement items.

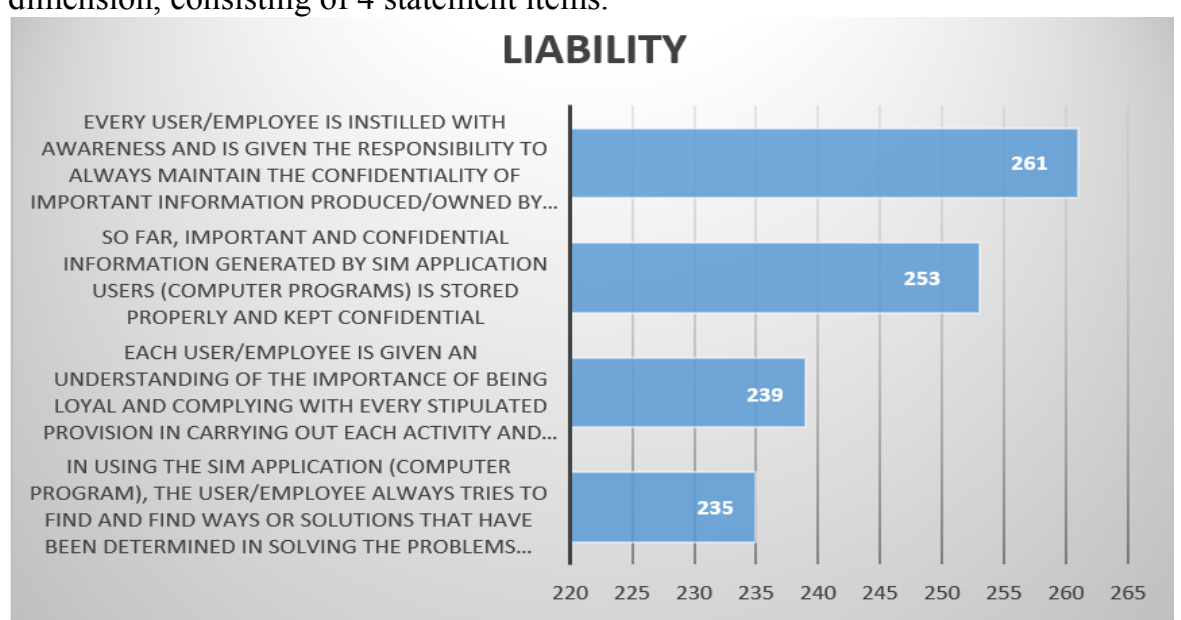

Figure: 4 respondents' answers about Liability

Based on the picture above, in statement (P1) the majority of respondents answered agree, which means that in using the SIM application (computer program) users/employees always try to find and find ways or solutions that have been determined in solving the problems faced well, and has a score of 235. While in statement (P2) the majority of respondents answered agree, which means that if every user/employee is given an understanding of the importance of being loyal and complying with every provision set out in carrying out each activity, so that it can solve various problems there is already good with a score of 239. While in the statement ( P3) the majority of respondents answered agree, which means that so far, important and confidential information generated by SIM application users (computer programs) is stored properly and kept confidential very well with a score of 253 , as well as question (P4) the majority of respondents answered agree which means that every user/employee has been instilled with awareness and is given the responsibility to always maintain the confidentiality of important information produced/owned by the company. with a score of 261 . Based on the 4 statements as indicators of the ethical dimension system of Islamic bankingin Indonesia with a total score of 988, which means that the ethicsusers system of Islamic Bankingin Indonesia is good with regard to aspects of the liability so as to support the trust and banking activities trustworthy

Of the 12 criteria used to measure the ethical dimensions of system users, the highest score was obtained at 
261 which indicates that Islamic Banking in Indonesia has instilled awareness in each of its employees as system users to be responsible for maintaining the confidentiality of important information produced / owned by the company. While the lowest score is 218 which is obtained for the criteria which indicate that there are still employees as system users who are not fully responsible for carrying out the assigned tasks, so that the results obtained are not maximized.

\section{Overview of the Variables of Management Accounting Information System Quality Variables}

The quality of management accounting information systems has 9 statements consisting of 3 dimensions, namely the dimensions of integration, flexibility and accessibility, where the integration dimension consists of 4 statements, the flexibility dimension consists of 3 statements, and the dimensions of flexibility consist of 3 statements. accessibility consists of 2 statement items. The following will present and explain the tendency of respondents' answers to the management accounting information system quality variable which consists of the dimensions of integration, flexibility and accessibility with a frequency and percentage distribution approach.

1. Integration

following is presented in the table recapitulation of respondents' responses that have been proposed to measure the variable Quality ofsystems management accounting informationthrough the integration dimension which consists of 4 statement items.

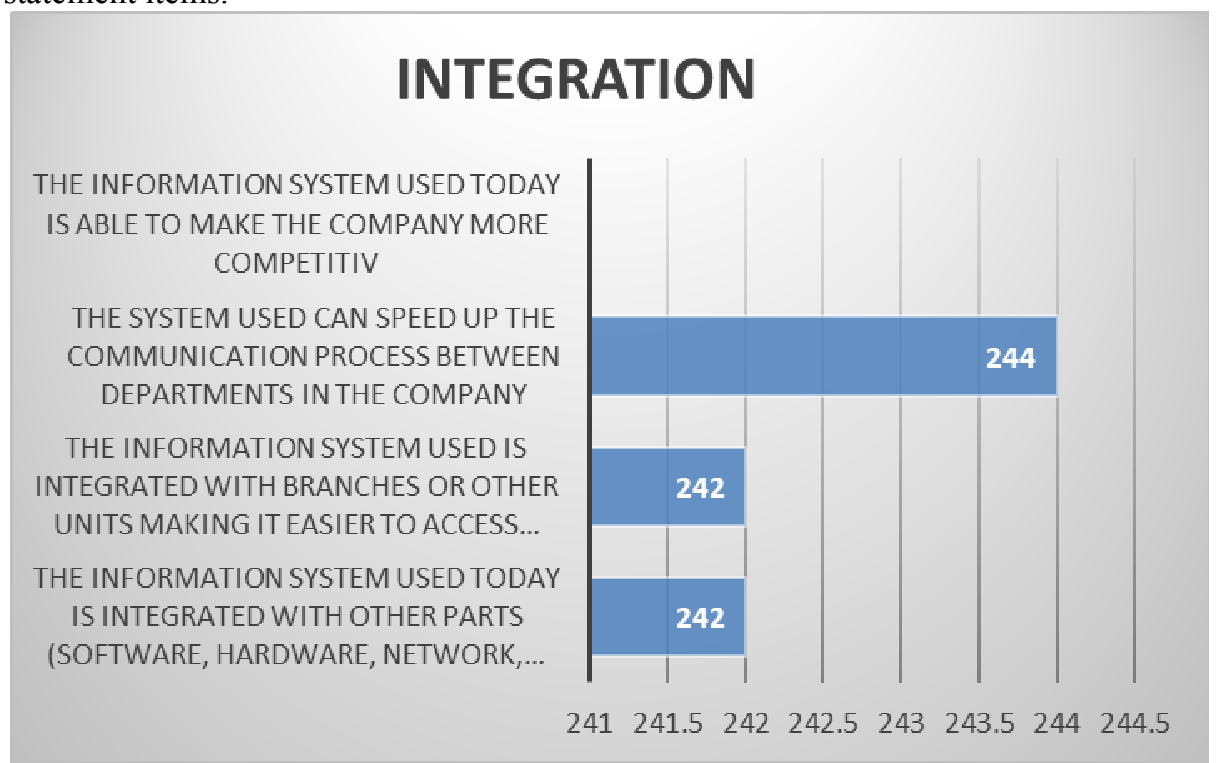

Figure: 5 respondents' answers about integration

Based on the figure above, in statement (P1) the majority of respondents answered agree, which means that thesystem informationcurrently used is integrated with other parts (software, hardware, network, integrated database) so that it is easy to access data required, are included in the good category with a score of 242 . While in statement (P2) the majority of respondents answered agree, which means thesystem informationused is integrated with branches or other units making it easier to access the required data, is included in the good category with a score of 242. Meanwhile in the statement (P3) the majority of respondents answered agree which means the system used at BSI has been able to speed up the communication process between departments and has been carried out well with a score of 244, as well as question (P4) the majority of respondents answered agree which means thesystem informationused when This is able to make the company more $\mathrm{h}$ is competitive with other companies, with a score of 248 . For the Integration dimension, seen from all statements, a total score of 976 is obtained, which means that thesystem is management accounting information banking Indonesian Islamicwell integrated, both integration between components and integration between sub-systems.

2. Flexibility

following is presented in the table of respondents' responses that have been proposed to measure the dimension of flexibility which consists of 3 statements, as shown in the table below: 


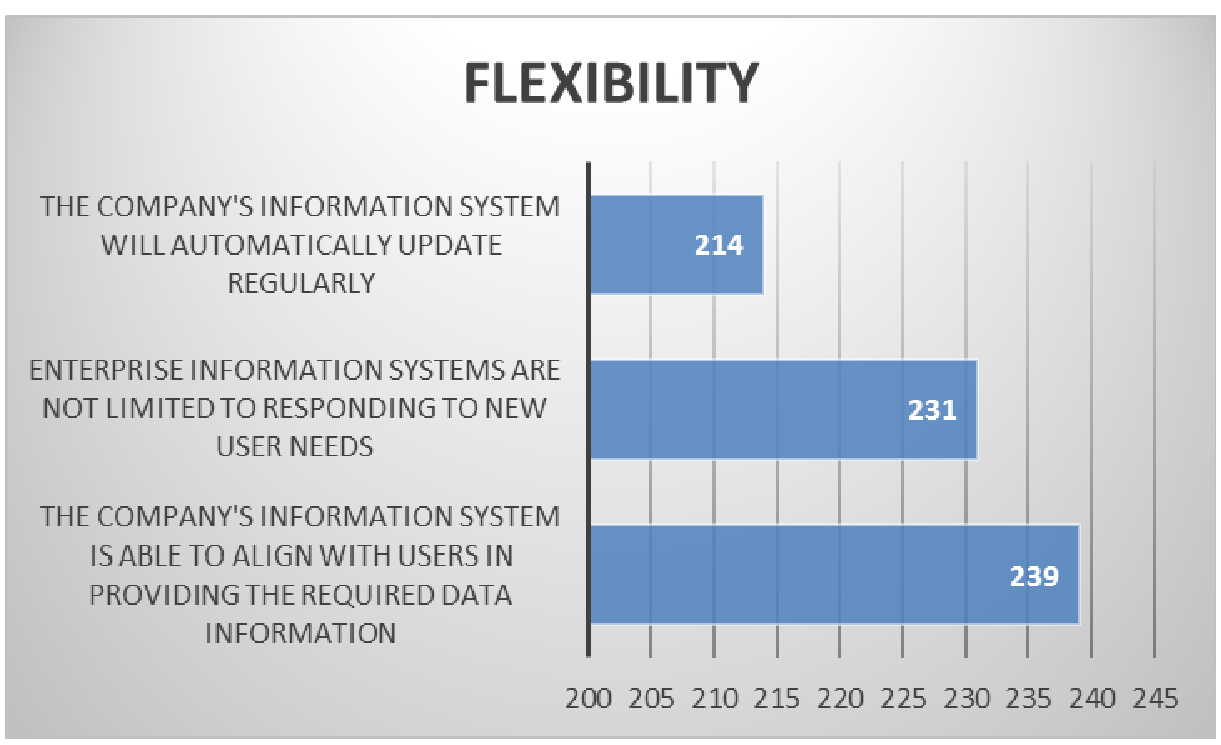

Figure 6 respondents' answers about Flexibility

Based on the picture above, in statement (P1) the majority of respondents answered agree which means that the information system used by the company is able to align with the user in providing the required data information with a score of 239, while the question (P2) the majority of respondents answered agree, which means that the company's information system is not limited in responding to the new needs of users with a score of 231, and (P3 ) the majority of respondents answered agree, which means the information system used automatically always updates regularly. So that the resulting information is relevant according to the needs of system users, with a score of 214 . While the overall total is 684 , which means that the management accounting information system used by Indonesian Islamic banking is flexible or easy to adapt to changes.

3. Accessibility

following table presents the recapitulation of respondents' responses that have been proposed to measure the variable Quality ofsystems management accounting informationthrough the accessibility dimension which consists of 4 statement items.

\section{ACCESIBILITY}

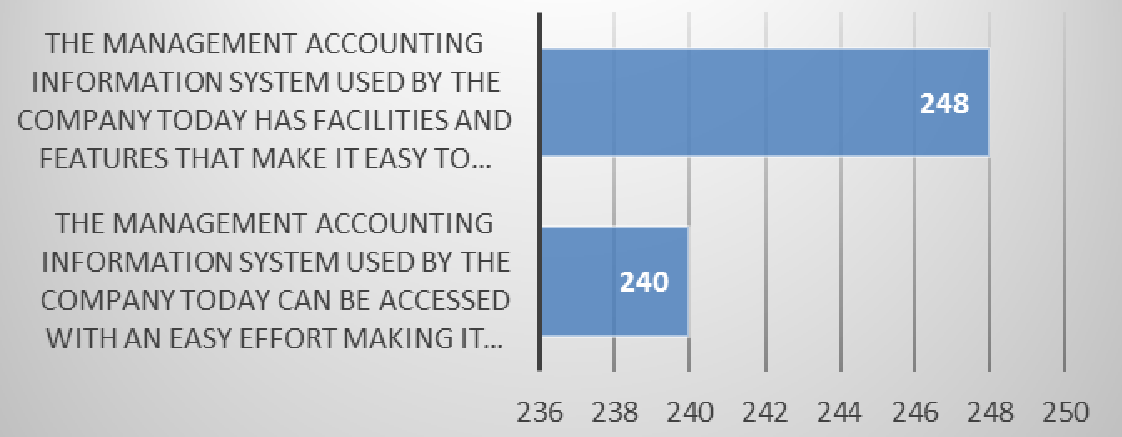

Figure 6 respondents' answers about Flexibility

Based on the picture above, in statement (P1) the majority of respondents answered agree, which means that thesystem current management accounting informationcan be accessed with an easy effort making it easier to get the information needed to complete the job well. with a score of 240. While in statement (P2) the majority of respondents answered agree, which means that thesystem management accounting informationused today has facilities and features that make it easy to access even though the user is outside the office so that it really helps the successful implementation of office tasks with a score of 248. So that the total quality of the management accounting information system with the dimension of accessibility is in the good category because it has a score of 488. This means that the management accounting information system owned by Indonesian Islamic banking is easily accessible by system users.

Of the 9 criteria used to measure the Quality of Management Information Systems, the highest score was obtained at 248 which indicates that the Management Accounting Information System implemented has been able to make Islamic Banking in Indonesia more competitive and the management accounting information 
system used by the company currently has facilities and features that makes it easy to access even though the user is outside the office so that it really helps the successful implementation of office tasks. While the lowest score was obtained at 214 , which indicates that the company's management accounting information system has not fully automated updates on a regular basis.

\section{Verification Analysis}

\section{Hypothesis Testing Design Hypothesis}

testing aims to determine whether there is an influence between the variables in this study. This test is done by simple linear regression analysis where the data presented must be normal. To find out normal or not, the data normality test was carried out. Normality test is used to test the normality of the data that has been collected. As for the normality test in this study using Kolmogorov Smirnov, the following are the results of the normality test processed using SPSS version 23 as follows:
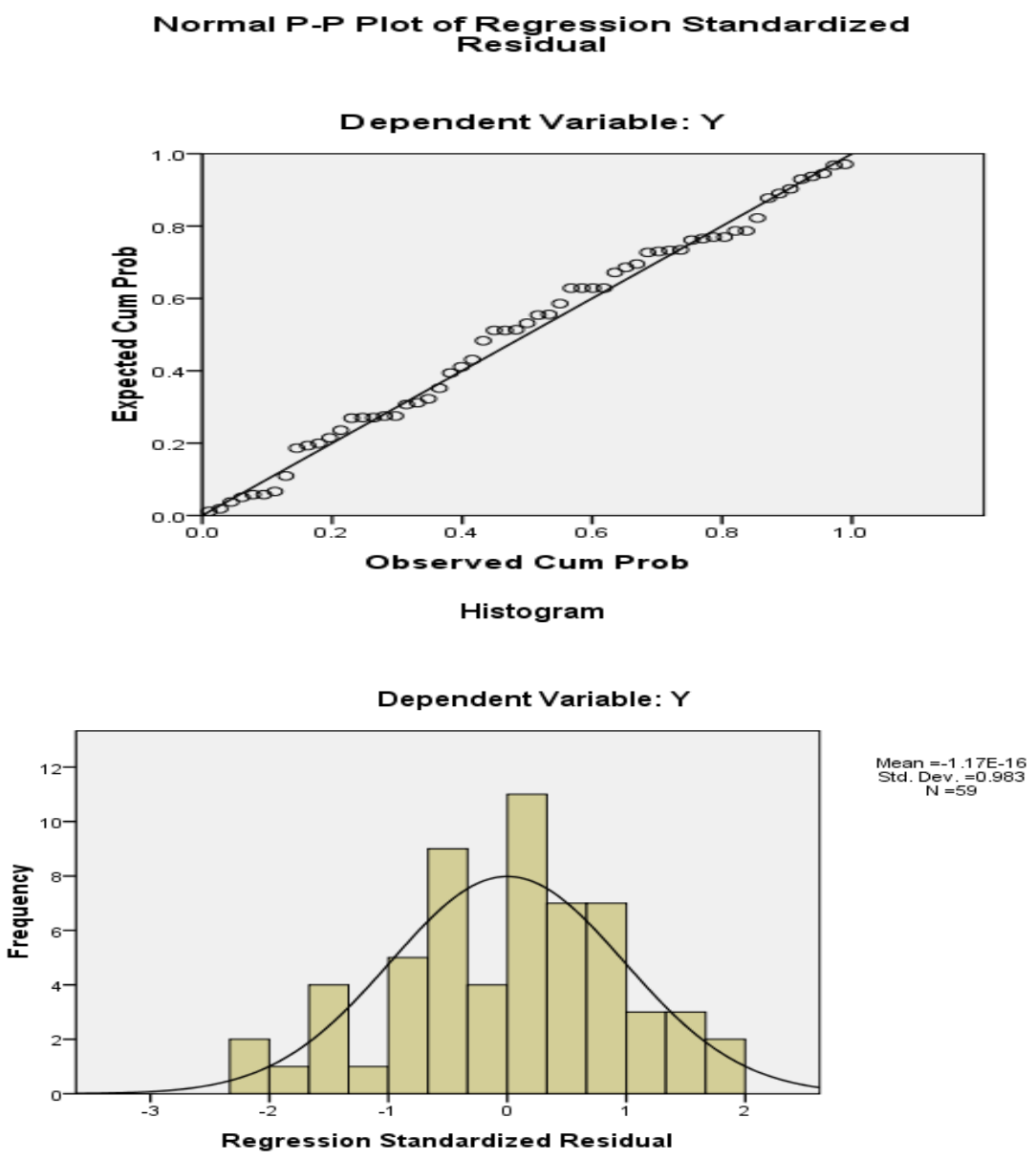

Figure 1. Histogram and PP Plot

Based on the output chart display above, we can see the histogram graph and plot graph. Where the histogram graph gives a distribution pattern that deviates to the right, which means that the data is normally distributed. Furthermore, the p-plot image shows the points following and approaching the diagonal line so that it can be concluded that the regression model meets the assumption of normality.

\section{Simple Linear Regression Simple}

linear regression aims to estimate the dependent variable and is carried out to analyze the hypotheses made in this study. The following are the details of the results oflinear regression testing simple. 
Table 1 Results of Simple Linear Regression Coefficients

\begin{tabular}{|c|c|c|c|c|c|}
\hline \multirow[b]{2}{*}{ Model } & \multicolumn{2}{|c|}{ Unstandardized Coefficients } & \multirow{2}{*}{$\frac{\text { Standardized Coefficients }}{\text { Beta }}$} & \multirow[b]{2}{*}{$\mathbf{t}$} & \multirow[b]{2}{*}{ Sig. } \\
\hline & B & Std. Error & & & \\
\hline 1 (Constant) & 1,985 & 6,573 & & .302 & .764 \\
\hline ETIKA_PENGGUNA & .842 & .134 & .6 & 6299 & .0 \\
\hline
\end{tabular}

a. Dependent Variable: KUALITAS_SIA, Sourceresults processing Data

Based on the data in the table above it can be formulated in hypothesis testing equation as follows:

KSIA $=1.985+0.3842 \mathrm{EP}+\mathrm{e}$

Information:

KSIA: Quality of Accounting Information Systems

EP: User Ethics

From the results of the regression equation each variable can interpreted as follows:

a. $\quad 1.985$ means that if thevariable User Ethics constant value then variable Quality of Accounting Information System increased by 0.3842 .

b. $\quad 0.3842$ means that if the User Ethics variable increases by one unit, the variable Quality of Accounting Information System increased by 1,985 .

\section{Hypothesis Testing Results}

1. Partial Test (t-test)

Partial test or t-test aims to determine the individual influence of each independent variable, namely the influence of user ethics on the quality of accounting information systems. The following are the details of the results of the partial test or t test:

Table 2 ANOVA

\begin{tabular}{|ll|r|r|r|r|r|}
\hline Model & & Sum of Squares & df & Mean Square & F & Sig. \\
\hline 1 & Regression & 548,943 & 1 & 548,943 & 39,672 & $000^{\mathrm{a}}$ \\
& Residual & 788,718 & 57 & 13,837 & & \\
& Total & 1337,661 & 58 & & & \\
\hline
\end{tabular}

a. Predictors: (Constant), ETHICS_USER

b. Dependent Variable: QUALITAS_SIA

Based on the test results above, a significant value is obtained from the ethics of system users of 0.00 which is smaller than 0.05 so it can be concluded from this partial test ( $t$ test) that the hypothesis is accepted, meaning that the system user ethics has a significant and positive effect on the quality of the accounting information system

\section{Simultaneous Coefficient of Determination (R square)}

Coefficient of determination Rsquare aims to measure the extent to which the ability of the regression model to explain the variation of the dependent variable or the variable of Management Accounting Information System Quality. The following details the results of the coefficient of determination (R2):

Table 3 Results coefficient of Determination (Rsquare)

Model Summary

\begin{tabular}{|l|c|r|r|r|}
\hline Model & $\mathrm{R}$ & R Square & Adjusted R Square & Std. Error of the Estimate \\
\hline 1 & $.641^{\mathrm{a}}$ & .410 & .400 & 3.71983 \\
\hline
\end{tabular}

a. Predictors: (Constant), ETHICS_USER

Based on the table above, the coefficient of determination (rsquare) is obtained simultaneously at 0.410 or in percentage of $41.0 \%$. This shows that the quality of the accounting information system can be influenced by user ethics with a total contribution of $41.1 \%$, while the remaining $59 \%$ is the influence or contribution of other factors not examined in this study.

\section{Discussion}

Effect of User Ethics on the Quality of Management Accounting Information Systems

Based on hypothesis testing, it turns out that User Ethics has a significant and positive effect on the quality of management accounting information systems in Indonesian Islamic Banking. This means that the better the user 
ethics, the more quality the application of management accounting information systems will be. The results of this study are supported by a statement according to Rocheleau (2006:264) which reveals that ethics is related to information systems. More O'Brien \& Marakas (2011:20) emphasized that as managers, professional employers and employees must have ethical responsibilities in the use of information systems. Another opinion regarding the relationship between ethics and information systems was conveyed by Hall (2011:112) that ethics is closely related to business, information systems and computer technology.

Myers \& Venable (2014) study results concluded that there are 6 (six) ethical principles that must be applied in the use of information systems, includingthe public interest, informed consent, privacy, honesty and accuracy, property and quality of the artifact. Piccoli (2008:450) states that ethics is related to information systems, meaning that when an information system is implemented, ethics becomes a guide for user behavior in accordance with the rules applied. Laudon \& Laudon (2014:152) argues that one must understand how ethically correct is required in the use of information systems.

Next Olumoye (2013) in his research revealed that ethics in this case the responsibility and accountability of a person is very necessary in carrying out their activities in the context of developing information systems. This agrees with Chen et al. (2011) in his research that user responsibility has an important role in improving the performance of information systems. Ethical issues are an important and unavoidable element of information systems. in an organization pay attention to the ethics of users, so it can be said that user ethics affects the quality of accounting information systems.

System users in Indonesian Islamic Banking have implemented various ethics adequately. It is proven that inthe use of system applications (computer programs) users/employees always try to find and find ways or solutions that have been determined in solving the problems faced properly, and have a score of 235. Meanwhile, another fact is obtained thatif every user/employee is given an understanding of the importance of being loyal and complying with every provision stipulated in carrying out each activity, then various problems can be resolved properly and the score is 239 . The next fact is that so far, important information and secrets generated by SIM application users (computer programs) are stored properly and kept confidential very well with a score of 253, as well as every user/employee has been instilled in awareness and given the responsibility to always maintain the confidentiality of important information produced/owned company, with a score of 261.

Overall, from the description above, it can be said that the ethics of system users in Indonesian Islamic Banking are good so that they can support trustworthy and trustworthy banking activities, so that they will be able to play a role in improving the quality of the management accounting information system. However, from the results of the lowest score of 218, there are still weaknesses that must be a concern for the management, namely there are still employees as system users who are not fully responsible for carrying out the assigned tasks, so the results obtained are not optimal.

\section{CONCLUSION}

Based on the results of research and discussion, the following conclusions can be drawn: The system users in Indonesian Islamic Banking have implemented ethics well, so that it can support the quality of the management accounting information system, but there are still weak points, namely there are still employees as system users who not fully responsible for carrying out the assigned tasks, so the results obtained have not been maximized.

\section{REFERRENCE}

Arikunto, Suharsimi. 2002. Metodologi Penelitian. Jakarta: Rineka Cipta. 2006. Prosedur Penelitian : Suatu Pendekatan Praktik. Jakarta: Rineka Cipta.

Azhar Susanto.2013. Sistem Informasi Akuntansi, struktur-Pengendalian-Resiko- Pengembangan, Lingga Jaya. Bandung.

Badudu JS dan Zain, Sutan Mohammad. 2010. Kamus Umum Bahasa Indonesia.Jakarta: Pustaka Sinar Harapan. Bagranoff, NA.,Simkin,MG,m dan Norman, CS,2010,Core concepts of: Accounting Information System, Eleventh Edition.John Wiley \& Sons, Inc.

Baltzan, P. 2012. Business Driven Information Systems. New York: Irwin/McGraw- Hill.

Bodnar, George H., and William S. Hopwood. 2010. Accounting System Information. Pearson.

Hayatunnufus, Tissya. 2015. Pengaruh Kompetensi Pengguna (User) Terhadap Penerapan Sistem Informasi Akuntansi Dan Implikasinya Terhadap Kualitas Informasi Akuntansi. Bandung. Universitas Widyatama.

Darmin Nasution. 2013. Pengakuan darmin Nasution dibalik kasus Elnusa-bank Mega. Melalui http://www.merdeka.com/uang/pengakuan-darmin-nasution-dibalik kasus elnusa-mega.html.4 November 2013

Fung Jen, tjhai. 2002. Faktor - faktor yang mempengaruhi kinerja sistem informasi akuntansi. Jurnal bisnis dan akuntansi volume IV No. 2.

Gelinas.UJ , Dull,RB \& Wheeler,PR 2012. Accounting Information System. USA: South-Western Cengage Learning. 
Ghozali, Imam. 2006. Aplikasi Analisis Multivariate Dengan Program SPSS. Semarang: Badan Penerbit Universitas Diponegoro.

Ghozali, Imam, Hengky Latan. 2015. Konsep, Teknik, Aplikasi Menggunakan Smart PLS 3.0 Untuk Penelitian Empiris. Semarang. Badan Penerbit Universitas Diponegoro.

Hall, James. 2011. Sistem Informasi Akuntansi. Jakarta: Salemba Empat.

Hasan Bisri.2010. Ada Rekayasa akuntansi dalam kasus Bank century, melalui http://lipsus.kompas.com/aff2012/read/2010/01/04/15040360/adarasalakuntansi.dalam kasus.bank.century. 4 januari 2010

Husein Umar. 2005. Metode Penelitian. Jakarta : Salemba Empat.

Joni Swantanto.2011.BI nilai ada 5 titik Rawan Operasional Bank melalui http:// finansial.bisnis.com/read/20110607/90/40314/bi-nilai-ada—titik-rawan-operasional-bank.

Selasa, $07 / 06 / 2011$.

Kadir, Abdul dan Terra CH. Triwahyuni. 2013. Pengenalan Sistem Informasi.

Yogyakarta: Andi.

Laudon, Kenneth \& Laudon, Jane P 2014. Management Bagranoff, NA.,Simkin,MG,m dan Norman, CS,2010,Core concepts of: Accounting Information System, Eleventh Edition.John Wiley \& Sons, Inc Information Systems: Managing The Digital Firm, Thirteenth edition. Essex: Pearson Education Limited.

McLeod, R. \& Schell, GP 2007. Management Information Systems. Bandung: Salemba Empat.

Moeheriono. 2012. Pengukuran Kinerja Berbasis Kompetensi. Jakarta: PT.Raja Grafindo Persada.

Mulyadi. 2001. Sistem Akuntansi. Jakarta : Salemba Empat. 2006. Sistem Akuntansi. Jakarta: Salemba Empat. 2010. Sistem Akuntansi. Jakarta: Salemba Empat.

Myers Michael D \& Venable, John R.2014.A Set of Ethical Principles for Design Science Research information System. Information \& management.51. Pp.801-809

Narimawati, Umi. 2010. Penulisan Karya Ilmiah. Jakarta: Penerbit Genesis.

N Nurhayati.et al (2015), User Participation On System development, User Competence and Top Management Commitment and Their Effect On The Success Of The Implementation Of Accounting Information System (Empirical study in Islamic Bank in Bandung)

Noor, Juliansyah. 2013. Analisis Data Penelitian Ekonomi \& Manajemen. Jakarta.PT Gramedia Widia Sarana Indonesia.

O'Brien, James A \& Marakas, George M. 2010. Introduction to Information Systems. $15^{\text {th }}$ Edition. McGrew-Hill Irwin.

Piccoli, Gabriele,2008. Information System for Managers. Tex and Cases,USA: John Wiley \& Sons Inc. United States of America.

P. Robbins, Stephen. 2008. Organizational Behaviour (Perilaku Organisasi). Jakarta : Salemba Empat.

Rahmi, Mardia. 2013. Pengaruh Penggunaan Teknologi Informasi Dan Keahlian Pemakai Terhadap Kualitas Informasi Akuntansi (Studi Empiris Pada Perusahaan Bumn di Kota Padang). Thesis. Universitas Negeri Padang.

Rani, DL., \& Kidane, F,2012. Characteristics and Important Quality Factors of Management Accounting Information System. Radix International Journal of Banking, Finance and accounting (RIJBFA) Volume I, Issue 7.

Richardson,., Chang dan Smith, R.2014. Accounting Information System. McGraw-Hill International Edition.

Rocheleau, Bruce,2006. Public Management Information System. 2006.All right Reserved.

Rogerson, Simon, Weckert, John \& Simpson, Cris, 2000. An Ethical perspective on Information System Evaluation. International Journal Of Agile Management System 2/3.2000.Pp 233-241.

Romney, Marshall B. Dan Steinbart, Paul John. 2014. Accounting Information System. Jakarta: Salemba Empat.

Romney, Marshall B \& Steinbart, Paul J.2015. Accounting Information Systems. Global Edition. Thirteenth Edition,USA: Pearson Education Limited.

Sekaran, Uma dan Bougie, Roger. 2013. Research Methods for Business. United Kingdom: John Wiley \& Sons Ltd.

Spencer, Lyle M. And Signe M. Spencer. 1993. Competence Work: Model for Superior Performance. John Wiley and Sons, Inc.

Sugiyono. 2010. Metode Penelitian Pendidikan Pendekatan Kuantitatif, kualitatif, dan R\&D. Bandung: Alphabeta. 2011. Metode Penelitian Bisnis. Bandung: Alphabeta. 2012. Metode Penelitian Bisnis. Bandung: Alphabeta.

2013. Metode Penelitian Kuantitatif Kualitatif dan $R \& D$. Bandung: Alphabeta. 2014. Metode Penelitian Kuantitatif Kualitatif dan R\&D. Bandung: Alphabeta. 2014. Metode Penelitian Bisnis. Bandung: Alphabeta. 
Sunyoto, Danang. 2013. Metodologi Penelitian Akuntansi. Bandung: PT Refika Aditama Anggota Ikapi. Susanto, Azhar. 2013. Sistem Informasi Akuntansi. Bandung: Lingga Jaya.

Tho]mpson, Ronald L., Haggings, Christoper A., Dan Howell, Jane M. 1991. Personal Computing: Toward a Conceptual Model of Utilization. Mis Quarterly.

Triandis, HC 1980. Values, Attitudes and Interpersonal Behavior. Lincoln, NE: University of Nebraska Press. 